\title{
AN EMPIRICAL APPLICATION OF PROBABILISTIC COST-BENEFIT ANALYSIS: THREE CASE STUDIES ON DAMS IN MALAYSIA, NEPAL AND TURKEY
}

\author{
R. MORIMOTO \\ CERMAS, Toulouse Business School, France.
}

\begin{abstract}
This paper empirically applies cost-benefit analysis (CBA) to much debated hydropower projects in Malaysia, Nepal and Turkey. The study selects an interesting mixture of cases, as the main characteristics of each dam, the geographical locations of each dam, and the development stage of each country differ. The study brings together all the major issues attached to each hydropower project and estimates the quantitative impacts of these controversial dams. The CBA model in this study takes into account the premature decommissioning of dams and the correlation between the parameters of generation capacity, total construction cost, and construction period. The mean cumulative net present value (NPV) at the 100th year of the analysis with the 5\% discount rate for the Sharada-Babai Dam in Nepal shows a positive figure, whereas the mean cumulative NPV after 100 years for both the Bakun Dam in Malaysia and the Ilisu Dam in Turkey are negative. The mean cumulative NPV for Sharada-Babai becomes negative when the pure rate of time preference is larger than $6 \%$; for Bakun and Ilisu, it converges to zero as the pure rate of time preference becomes larger. The sensitivity analysis shows the dominant positive impact of the generation capacity parameter on NPV for Bakun, and the parameter expressing initial expected increase in economic output for Sharada-Babai and Ilisu.

Keywords: Bakun Dam, cost-benefit analysis, hydropower development, Ilisu Dam, net present value, sensitivity analysis, Sharada-Babai Dam.
\end{abstract}

\section{INTRODUCTION}

The serious negative effects of large dams have been widely discussed, and the roles of large dams have been questioned, over the past two decades [1]. However, there are still numerous plans to build massive dams worldwide, especially in developing countries. Are these dams really worthwhile to build? Will they contribute to the sustainable development process? This paper tries to answer these questions based on an empirical application of probabilistic cost-benefit analysis (CBA) to much debated hydroelectric projects in Nepal, Malaysia and Turkey. The study selects an interesting mixture of cases, as the main characteristics of each dam, the geographical locations of each dam, and the development stage of each country differ. The study brings together all the major issues attached to each hydropower project and estimates the quantitative impacts of these controversial dams. The CBA model in this study has been developed from the previous version used by Morimoto and Hope [2, 3], in order to take into account the correlation between the generation capacity, the total construction cost, and the construction period.

The characteristics of the three hydropower projects are described in Section 2. Section 3 explains the methodology and lists the variables used in the model. Section 4 presents the findings from the study including sensitivity analysis and the variation of cumulative net present value (NPV) against the pure rate of time preference. Section 5 summarizes and concludes the study.

\section{CASE STUDIES}

\subsection{Malaysia: Bakun Hydroelectric Project}

Together with rapid economic growth, electricity consumption in Malaysia grew at $5.6 \%$ between 2000 and 2005, according to the APEC Energy Demand and Supply Outlook 2006. Electricity demand in 
Malaysia is mainly met by three major sources: gas (47\%), hydropower (10\%), and coal (43\%), according to the Tenaga National Berhad (TNB) in 2005 (http://www2.tnb.com.my/tnb/pdf/GenStats.pdf). The government intends to balance this ratio and tries to increase hydropower generation, which has led to the controversial Bakun Hydroelectric Project construction plan. The Bakun Dam on Balui River in Sarawak state on Borneo Island will be Southeast Asia's largest dam with a generation capacity of $2.4 \mathrm{GW}$, and is supposed to cater to the rising industrial demand for electricity in Malaysia. Although this development of a remote part of Malaysia might improve the regional economy, through increased employment and infrastructure development such as access roads and airports, there are also many costs associated with it. It will flood 70,000 ha of rainforests and abundant timber sources, equivalent to the size of Singapore, and fertile agricultural lands. The construction costs for this gigantic project will be huge, despite the fact that there would be a possibility of insufficient demand to absorb its enormous generation of electricity. Another great concern owing to this project is the displacement of 10,000 indigenous people. The entire ecosystem of the area might also change; especially large negative effects on downstream fishery are anticipated. The area is already suffering from siltation due to timber extraction, which is very likely to restrict power generation capacity in the near future. Poor working conditions at the dam site have also been reported. The project has been delayed due to serious environmental, social, and financial problems. The project was originally scheduled to be completed in 2003; however, it has been revised to 2007.

\subsection{Nepal: Sharada-Babai Hydropower Project}

The electricity demand in Nepal is estimated to grow at 7.5\% annually until 2020 [4]. Lack of electricity may restrict economic growth, especially in the industrial and service sectors - the fastest growing economic sectors in Nepal [5]. The electrification rate in Nepal is still very low - only about one-third of the population has access to electricity, and the rate is much lower for the rural population [4]. The country's major sources of energy for the rural population are fuel wood and kerosene [6]. The government in Nepal plans to provide electricity to 55\% of the population by 2007, which requires the rapid expansion of electrification in the country [4]. Nepal has great potential for hydropower and its theoretical generation capacity is $83 \mathrm{GW}$ according to the Nepal Electricity Authority (NEA). Currently, there are many hydropower projects in the planning stage in Nepal, in order to utilize the resources.

The proposed Sharada-Babai Hydropower Project in the mid-western region of Nepal has an installed capacity of $93 \mathrm{MW}$, and requires a 5-year construction period. The project is located between the tropical and subtropical climatic regions of the country. The land of the reservoir area is very fertile and the main crops grown are paddy and wheat. More than 300 families will be relocated from the core project area. The major impact of the project will be the submergence of rich forest and agricultural land. The impoundment and reduced flow downstream will change the hydrology of the basin, which is likely to affect the aquatic environment of the river. The holy pond and the Kali Vhagwati (a temple of religious and cultural importance) will be inundated due to the reservoir formation. Infrastructure relocation such as a school, a post office, and suspension bridges is also required.

\subsection{Turkey: Ilisu Hydroelectric Project}

Electricity consumption in Turkey has been growing at the rate of $6 \%$ per year as a result of rapid urbanization and industrialization (Turkey's Energy Strategy by the Ministry of Foreign Affairs 2006). Electricity demand in Turkey is met by oil (38\%), coal (27\%), gas (23\%), and hydropower and renewable (12\%) sources, according to the Turkish Ministry of Foreign Affairs (2006). 
The proposed Ilisu Hydroelectric Project is a part of the Southeastern Anatolia Project, which aims to improve the living standards and develop the agricultural potential of the nine southeastern Anatolia provinces and to bring their socioeconomic level up to the national average. The Ilisu Dam is presently the largest hydropower project in Turkey with a generation capacity of $1200 \mathrm{MW}$. The dam will be located on the Tigris River in southeast Anatolia, $65 \mathrm{~km}$ upstream of the Syrian and Iraqi border. The project plan was stopped in 2002 as it was extremely controversial for a variety of political, social, environmental, economic, and archeological reasons. However, the project resurfaced in 2005.

The project will submerge approximately 52 villages and 15 small towns and affect between 25,000 and 78,000 people, mainly ethnic Kurds (http://www.rivernet.org/turquie/ilisu.htm). The people living in the project area are mainly farmers, who grow cereals, vegetables, fruits, cotton, tobacco, and herbs, and a small number of shepherds. Although there is no real commercial fishing in the Tigris River, farmers fish for local consumption. People moving to cities will face radical changes in their daily activities and traditional ways of life, which often cause significant problems of adaptation to the urban environment, family tensions, psychological stress, and social disruption.

Hasankeyf, the main town to be inundated, is the only town in Anatolia that has survived since the middle ages without destruction, and it is also known as an important pilgrimage center. The town's history dates back at least 2700 years, and it hosts a formidable array of monuments including cave churches, ornate mosques, and Islamic tombs. An astounding complexity of architectural and religious heritage spanning several civilizations has been created. Being a rich treasure of Assyrian, Christian, Abassidian-Islamic, and Osmanian history in Turkey, Hasankeyf was awarded complete archeological protection by the Turkish Department of Culture in 1978, and 22 monuments have been entered in the Turkish Cultural Inventory List in 1981. The lack of funds and time means that it will be difficult to relocate the treasures that will be inundated. Moreover, even after successful relocation, they may not create the same aesthetic impact in a new site. Hasankeyf is also a tourist destination and a holiday resort, so inundation of this town is likely to affect tourism in the area.

The area to be flooded by the reservoir includes 7353 ha of good agricultural land, 4820 ha of medium-low quality land, and 15,675 ha of land not suitable for growing crops (http:// www.rivernet.org/turquie/ilisu.htm). Since the amount of trees and shrubs in the area to be flooded is relatively small, the carbon dioxide released from the reservoir is assumed to be small compared to other reservoirs of the same size in dense forests [7]. Solid wastes and wastewater from major cities are being dumped into the Tigris River without any treatment. The Ilisu reservoir will vastly reduce the auto-purification capacity of the Tigris River, which is very likely to cause degradation of water quality and may also have a negative effect on downstream fishery.

\section{METHODOLOGY}

The CBA model used in this study is developed from the previous version used by Morimoto and Hope [2,3], in order to take into account the correlation between the generation capacity, the total construction cost, and the construction period. Table 1 lists the variables used in the CBA model: the core variables included in all the case studies are PG (power generation), CP (clean power), EG (economic growth), CC (construction cost), OM (operation and maintenance cost), RE (resettlement cost), IN (losses due to inundation of land), and AC (accident cost). The project specific variables are FI (impacts on downstream fishery) for Bakun, IF (infrastructure cost) for Sharada-Babai, and LT (tourism loss) and AS (archaeological loss) for Ilisu. A brief summary of the equations used in the model and all the parameters in the model and their values are listed in Appendices A.1 and A.2, respectively. Dixon et al. [8] argue that the appropriate time horizon should be long enough to encompass the useful life of the proposed project; therefore, the project life of 100 years is selected in this study. 
Table 1: Variables used in the CBA model.

Variable (core variables in bold)

EG (economic growth)

PG (power generation)

CP (clean power)

IN (losses due to land inundation)

AS (archaeological loss) ${ }^{1}$

CC (construction cost)

FI (impacts on downstream fishery) LT (tourism loss)

\section{OM (operation and maintenance cost)}

RE (resettlement cost)

IF (infrastructure relocation cost)

$\mathrm{AC}$ (accident cost)
Description

The forgone economic costs for electricity not generated, which will occur when an alternative power generation technology is not available.

Calculated by multiplying the quantity of electricity generated by the price of electricity. A possible reduction in the quantity of electricity generated due to sedimentation and changes in electricity prices are also included in the equation.

The environmental benefit of avoiding damage from air pollution when generating an equivalent amount of power by thermal power. This benefit will occur when an alternative power generation technology is available.

Financial values of forests and agricultural lands that will be inundated.

Approximated by the values of cultural antiquities being sold on the market.

Construction costs of the power station and transmission facilities.

Decline in revenue from fishery due to dam construction.

Losses in tourism revenue as a result of the dam construction.

Operation and maintenance costs for running the hydropower station.

Compensation to individuals and development costs for new houses and infrastructure. Theoretically, estimations of what resettled people are willing to accept are preferred as better estimates. However, those data are difficult to obtain and their results are not very reliable, especially in developing countries.

Costs required to relocate infrastructures that will be inundated.

During construction, operation and maintenance and special circumstances (technical failure, terrorism attack, or earthquake). Calculated by multiplying the estimated number of deaths and injuries due to the project and the economic value of deaths and injuries. Assumes that accident risks are not internalized in wages. ${ }^{2}$

\footnotetext{
${ }^{1}$ How archaeology is perceived is different from place to place and generation to generation [9]. Although there are many studies on how to place values on archaeological sites, there is no simple conclusion for this argument [9-13].

${ }^{2}$ This method does not take into account accident costs for alternative sources of supply for simplicity, as different risks are included for the alternative cases.
} 
Table 2: Correlation coefficients.

\begin{tabular}{llll}
\hline & GC-TCC & GC-Tc & TCC-Tc \\
\hline Bakun & 0.996 & 0.996 & 0.983 \\
Sharada-Babai & 0.98 & 0.9 & 0.79 \\
Ilisu & 0.99 & 0.82 & 0.9 \\
\hline
\end{tabular}

GC, generation capacity parameter; TCC, total construction cost; Tc, construction period.

Some inputs in the CBA model seem to be clearly correlated to each other. If the generation capacity were to be reduced, the total construction cost and the construction period would also be reduced accordingly. Hence, we assume that a minimum value for one of these variables implies a minimum value for the others. The same assumption is made for the most likely and maximum values. The correlation coefficients for each project based on these implications are shown in Table 2. The calculation is based on the following formula:

$$
\text { Correlation coefficient }[x, y]=\frac{\text { Covariance }[x, y]}{\text { Standard error }[x] \times \text { Standard error }[y]} \text {. }
$$

There is a wide range in the data for GC (generation capacity) in the Bakun case, as the project size might be drastically reduced due to the protests. The minimum, most likely, and maximum values are $0.5,0.7$, and $2.4 \mathrm{GW}$, respectively. Therefore, the consideration of this input dependency would be particularly important for Bakun.

The data are given as ranges, collected mainly from the existing project reports including environmental impact assessment reports and energy reports. Supplementary data are based on an extensive collation of information from past studies on similar topics, newspapers, Internet, and other relevant sources. The most appropriate data for each parameter are selected using my best knowledge on the energy policy of the country, their current situation, and the future direction of power generation. Best efforts have been made to find as accurate and representative data as possible. Visiting the project site and interviewing government officials, energy experts, policymakers, researchers, academics, environmentalists, and locals during fieldtrips to Malaysia, Nepal, and Turkey have greatly helped such decision-making processes.

Some of these data may not be very accurate or precise. Many of the values in Tables A.1, A.2, and A.3 are tentative and open to criticism. However, this is inevitable, as many variables are not readily quantifiable and some data have limited availability because of the project complexity or they simply do not exist. Repeated runs of the model yield a probability distribution of possible outcomes, which is a more defensible procedure than just using as inputs single values that are in reality not well known.

\section{RESULTS}

Table 3 and Fig. 1 depict the impact of each variable on the NPV for each project; EG, PG, and CC are significant in all the projects; IN for Bakun and Sharada-Babai; and AS for Ilisu. The impact of $\mathrm{CC}$ is huge, as much as EG but not as prolonged. The sharp decay of the positive impacts of EG and PG can be explained as a result of serious sedimentation problems. In comparison, AS and LT are long lasting negative impacts, and are also not recoverable once the dam is constructed.

For Bakun, the 5 th percentile, the mean, and the 95 th percentile of cumulative NPV with a premature decommissioning option at a $5 \%$ discount rate at $t=100$ years are US\$ $-9.6,-2.8$, and 7.0 
Table 3: Mean cumulative present values for the variables at $t=100$ years in US\$ billion.

\begin{tabular}{llccr}
\hline & & Bakun & Sharada-Babai & Ilisu \\
\hline PVEG & Economic growth & $+\mathbf{1 3}$ & $\mathbf{+ 0 . 1 8}$ & $\mathbf{+ 1 3 . 8}$ \\
PVPG & Power generation & $+\mathbf{3 . 6}$ & $\mathbf{+ 0 . 2 1}$ & $+\mathbf{3 . 3}$ \\
PVCP & Clean power & +0.9 & +0.03 & +0.5 \\
PVIN & Inundation loss & $-\mathbf{1 0 . 5}$ & $\mathbf{- 0 . 0 9}$ & $\mathbf{- 0 . 2}$ \\
PVAS & Archaeological loss & - & - & $\mathbf{- 9 . 5}$ \\
PVCC & Construction cost & $-\mathbf{4 . 5}$ & $\mathbf{- 0 . 1 4}$ & $-\mathbf{4 . 9}$ \\
PVFI & Fishery loss & -4.4 & - & -0.9 \\
PVLT & Tourism loss & - & - & -3.5 \\
PVOM & OM cost & -0.4 & -0.03 & -0.5 \\
PVRE & Resettlement & -0.1 & -0.003 & -1.0 \\
PVIF & Infrastructure relocation & - & -0.02 & - \\
PVAC & Accident cost & -0.03 & -0.0004 & -0.04
\end{tabular}

Note: Significant variables are expressed in bold letters.

Source: CBA model runs.
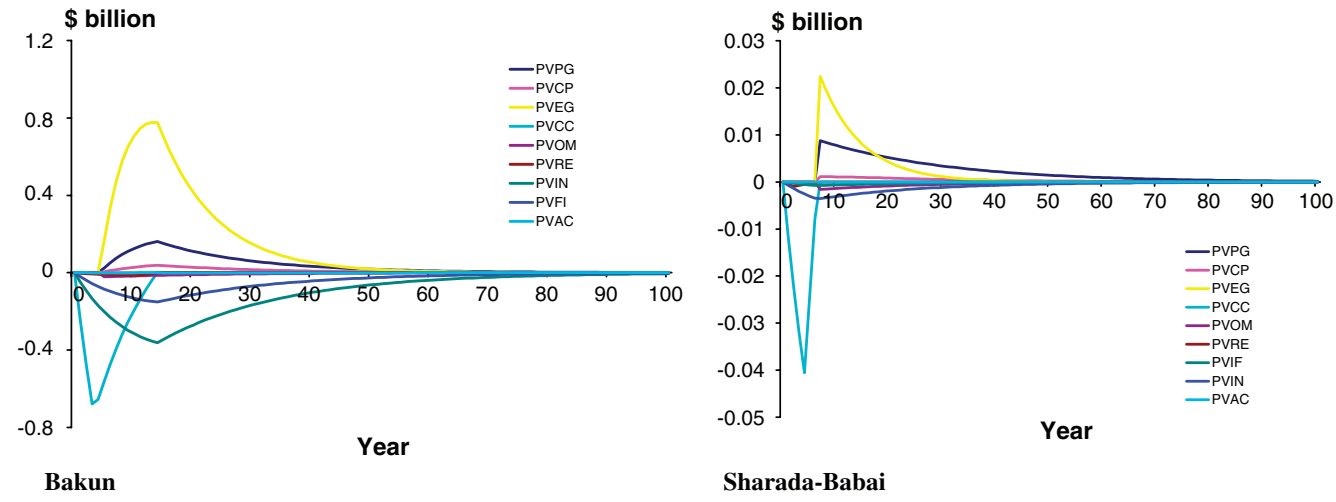

Sharada-Babai

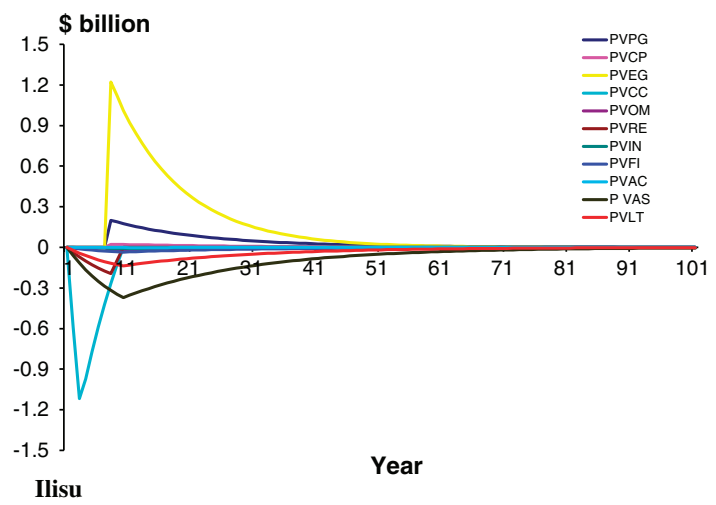

Figure 1: Present value of the variables in Table 1 by year. Source: CBA model runs. 
billion, respectively (without decommissioning they are US\$ $-9.9,-2.9$, and 7.0 billion, respectively, showing that the option of premature decommissioning gives a slight improvement). (The premature decommissioning option allows the dam to be closed early if the annual revenue drops below the annual avoidable costs.) The mean and the 5th and 95th percentiles of the cumulative NPV are all initially strongly negative due to the large construction cost as shown in Fig. 2. The 95th percentile recovers quickly after the construction is complete since the benefits of increased economic growth soon outweigh all the costs. Its peak is at $t=40$ years, as after this date the revenue is insufficient to cover the total annual costs. The 5th percentile and the mean values both remain negative throughout the life of the project. The mean shows a slight recovery from year 10 until year 30 followed by a permanent downward movement. The 5th percentile shows a similar pattern to the mean, though it already starts declining at $t=20$ years due to the large anticipated costs such as inundation and fishery losses.

For Sharada-Babai, the 5th percentile, the mean, and the 95th percentile of the NPV at the 5\% discount rate at $t=100$ years with the premature decommissioning option are US\$ $-0.009,0.14$, and 0.34 billion, respectively. The results without the premature decommissioning option are exactly the same since the recoverable costs such as $\mathrm{AC}$ (during the operation and maintenance period) and $\mathrm{OM}$ are small for this specific project. The range of cumulative NPV over time in Fig. 2] shows that the huge initial capital costs are gradually outweighed by the anticipated large benefits from power generation and increased economic growth.

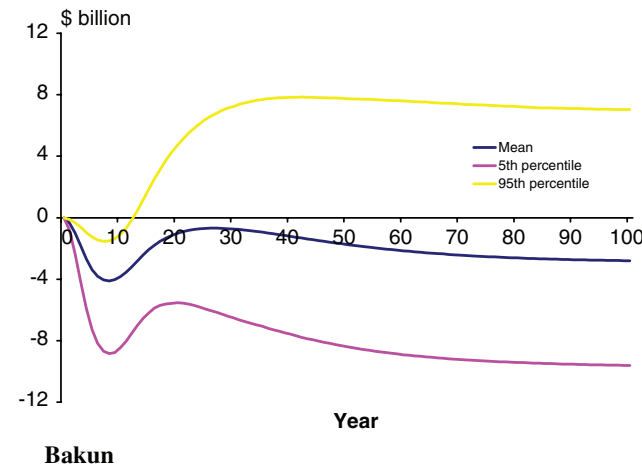

Bakun

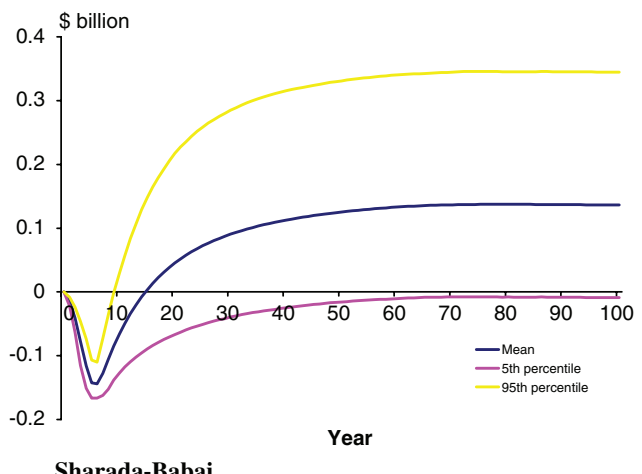

Sharada-Babai

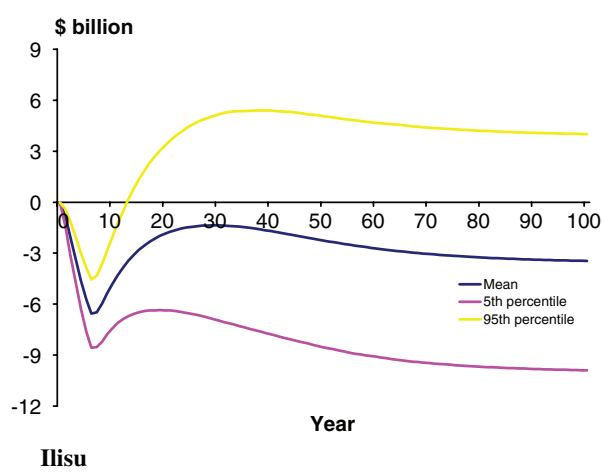

Figure 2: Range of cumulative NPVs at the 5\% discount rate by year. Source: CBA model runs. 
Table 4: Student $b$ coefficients.

\begin{tabular}{lccccc}
\hline Bakun & \multicolumn{3}{c}{ Sharada-Babai } & Ilisu \\
\hline GC & $+\mathbf{0 . 9 6}$ & EO & $+\mathbf{0 . 7 8}$ & EO & $+\mathbf{0 . 8 3}$ \\
EO & +0.63 & P0 & +0.34 & NT & -0.33 \\
TCC & -0.61 & GC & +0.30 & TCC & -0.28 \\
\hline
\end{tabular}

Note: The input parameter values are regressed against the output (NPV). The Student $b$ coefficient is a coefficient calculated for each input parameter in the regression equation. The most significant variables are expressed in bold.

Source: Sensitivity analysis runs.

For Ilisu, The 95th percentile is positive whereas the mean and the 5th percentile are negative as shown in Fig. 2. The mean, the 5th percentile, and the 95th percentile of the cumulative NPV at the $5 \%$ discount rate with the premature decommissioning option at $t=100$ years are US\$ $-9.9,-3.5$, and 4 billion, respectively. As Fig. 2 illustrates, the benefits never outweigh the costs throughout the period for the 5 th percentile and the mean, while the 95 th percentile turns to be positive soon after the completion of construction. The 95th percentile starts declining gradually after its peak at $t=40$ years. The NPVs are all negative at the beginning because of large construction and resettlement costs. The NPV increases rapidly once electricity generation starts; however, the mean and the 5th percentile remain negative as a result of huge archaeological losses from the destruction of this important area in Turkey which has numerous unique archaeological sites as well as tourist and pilgrim attractions. The result also shows that the consideration of premature decommissioning would not improve the outcome, since the recoverable costs after premature decommissioning such as OM, AC during operation, and IN for this project are relatively small.

\subsection{Sensitivity analysis}

The sensitivity analysis shows a dominant positive impact of GC on NPV for Bakun, and EO (initial expected increase in economic output) for both Sharada-Babai and Ilisu, as presented in Table 4. The parameters TCC, P0 (initial proportion of time during which an alternative power generation technology is not available), and NT (number of tourists visiting the dam site in the absence of the dam) also have significant impacts on NPV for at least one of the sites.

\subsection{Cumulative NPV against the pure rate of time preference}

Figure 3 plots the cumulative NPV against the pure rate of time preference, which illustrates that the NPV is sensitive to the change in discount rates. The mean value of the cumulative NPV for all projects converges towards zero as the pure rate of time preference becomes larger. For Bakun, the 95th percentile becomes negative when the pure rate of time preference is larger than $11 \%$. The mean value of the cumulative NPV for Sharada-Babai is positive when the pure rate of time preference is low, and becomes negative when the pure rate of time preference is larger than 6\%. The 95th percentile of the cumulative NPV for Ilisu becomes negative when the pure rate of time preference is larger than $8 \%$. 

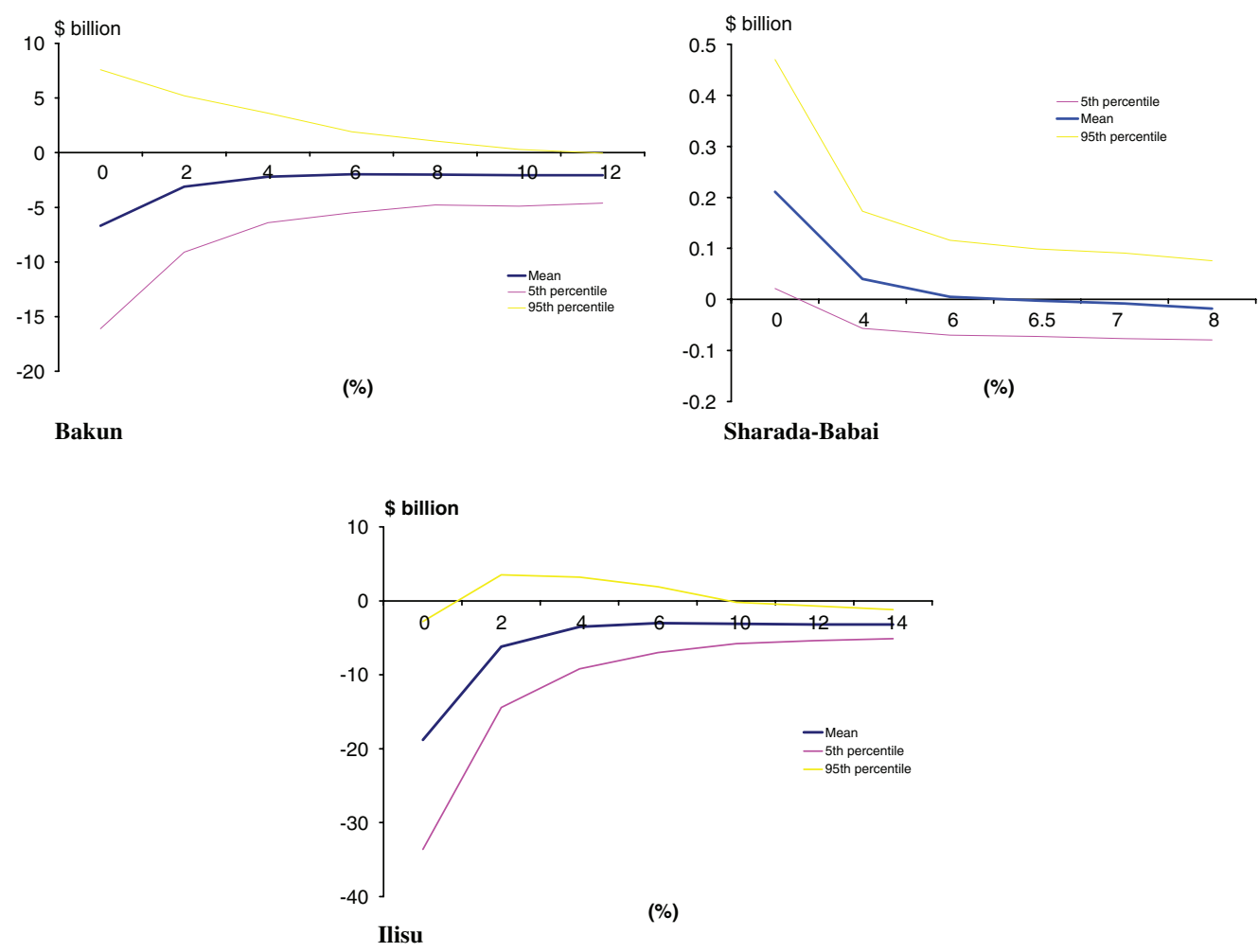

Figure 3: Mean cumulative NPV against the pure rate of time preference. Source: CBA model runs.

\section{CONCLUSION}

This study has examined the possible outcomes of three highly controversial dam projects in Malaysia, Nepal, and Turkey. The characteristics of each dam differ in terms of size, geographical locations, and the level of economic development. The CBA model developed by Morimoto and Hope [2, 3], which has been used previously to assess other hydropower projects, namely the Upper Kotmale Dam in Sri Lanka [2] and the Three Gorges Dam in China [3], has been applied to these case studies. The CBA model in this study is developed from the previous version in order to take into account the correlation between the generation capacity, the total construction cost, and the construction period. The model in the paper calculates the means and the ranges of present values for each impact of the proposed dams, both positive and negative. Thus, the model has identified the most significant impacts which are supported by numerical justification. The findings of the model, such as cumulative NPV, are shown by year. Thus, the model developed herein has a potential to help policymakers in their decision-making process, as it provides the whole picture of a project at a glance and it is possible to see the annual movements of each impact very clearly.

The result for the Bakun Dam in Malaysia shows huge expected losses due to the inundation of the dense rainforest and the fertile agricultural lands, and the significant negative impacts on downstream fishery. The benefits of the $2.4 \mathrm{GW}$ electricity supply and the facilitated economic growth might outweigh these massive losses. However, this is unlikely to occur during any feasible 
planning horizon, as can be seen from the 5th percentile and the mean of the cumulative NPV which are negative even after 100 years.

The result obtained for the Sharada-Babai Dam in Nepal presents a more positive outcome. There are large benefits from the increased economic growth due to increased power supply as the country is presently seriously short of electricity, large revenues from electricity sales, and the benefits of clean hydropower, in exchange for a large construction cost and the unrecoverable loss of submerging fertile agricultural land as well as forests. This study confirms that the improvement of hydropower development in Nepal seems to be crucial given the careful consideration of the consequences to the community and the environment.

The main finding for the Turkish Ilisu Dam is the enormous impact of the loss of unique archaeological sites, some of which date back at least 2700 years. The losses are not only the value of these cultural heritages and artifacts to be submerged, but also the significant number of tourists and pilgrims visiting the sites. Both the 5th percentile and the mean of the cumulative NPV depict that the proposed benefits of the project will not outweigh the large costs of the project. This result coincides with the fact that the project was postponed in 2002, due to significant social and environmental concerns.

The overall results show that large-scale dams generally tend to create large social and environmental impacts. The Nepalese dam case illustrates that smaller-scale dams seem to be more sustainable than gigantic scale dams. Furthermore, huge costs are involved in each of the projects discussed; therefore, an increase in electricity prices might not be avoidable. However, this may not be the case for the Sharada-Babai Project, as the benefit is likely to outweigh the cost soon after the construction.

The beauty of the model developed here is its flexibility: developers could choose from an array of variables that most closely fit the constraints and conditions of their individual case. Some of the available variables are either included or excluded in order to serve the differences in each project. These case studies with diverse individual concerns in this study have demonstrated that the generalized model can be a highly practical tool, with the great advantage of its simplicity and its ability to cater to almost any kind of hydropower project assessment under uncertainty. Moreover, the application of this type of probabilistic CBA model is not limited to assess only hydropower projects, but it is also possible to extend its use to assess other engineering or infrastructure projects such as new aircraft, water pipes, or tunnels [14].

The limitations of the model are that some impacts could be much larger than the impacts given here, though they may not be quantifiable. For example, the scale of the resettlement for the Bakun Dam is enormous and the resettlement impact is therefore expected to be huge, though this impact seems to be not fully reflected in our results. This suggests that current estimates of the resettlement cost might be too low, and that alternative approaches such as 'willingness to pay' or 'willingness to accept' might better estimate the true resettlement cost. Furthermore, some evaluations in the model might be oversimplified. There could be other possible impacts not considered for each project; some of these could be major, e.g. increased malaria infection, health problems caused by reduced water quality, and negative impacts on biodiversity in the area. Displaced people are further impoverished economically and suffer cultural decline, high rates of sickness, malnutrition, deaths, and great psychological stress in nearly every case (http://www.caa.org.au/campaigns/adb/fact_sheets/dams.html). Some of the dam sites, such as Bakun, are home to many unique species of fauna and flora, which may disappear due to the project's impact. The Bakun Dam site is located in dense forests; therefore, the $\mathrm{CO}_{2}$ release from the reservoir might not be negligible. These impacts have been omitted from the current analysis due to lack of data and the difficulty of quantifications. Including every single impact is not possible; therefore, the variables entered into the model are prioritized in each project assessment in this research. They could, however, be included in future analysis, if relevant, with sufficient background information. 


\section{ACKNOWLEDGMENTS}

Useful comments and feedback from Dr Chris Hope (University of Cambridge) are gratefully acknowledged. I would like to thank Dr Yusof Ahmad, Mr Ir Nordin Bin Ismali, and Mr Mohd. Zekri Yaakob from Malaysia TNB Hydro for their support towards the data collection and the field visits in Malaysia in December 2001. Many thanks also go to Mr Arjun Aryal (PhD at University of Hawaii, US) and Mr Bhupendra Aryal from WRC (Water Resource Consultant, Nepal) for providing useful data, information, and the project report on the Sharada-Babai Project, and for their great help during the field visit in October 2001.

\section{A.1 Model}

\section{APPENDIX}

A brief summary of the equations used in the model follows. (The complete set of equations is presented in detail in $[2,3]$.)

$\mathrm{EG}=$ (Proportion of time during which an alternative generation technology is unavailable) $\times$ (Quantity of electricity) $\times$ (Increased economic output due to increased electricity supply)

$\mathrm{PG}=$ (Quantity of electricity $) \times$ (Price of electricity $)$

$\mathrm{CP}=$ (Proportion of time during which an alternative generation technology is available) $\times$ (Benefit of avoiding air pollution due to reduced thermal power use)

IN $=$ Economic value of lost land

AS = Valuation proxies for lost cultural resources

$\mathrm{CC}=$ Annual construction cost

FI = Annual lost profit from fishery due to the dam

$\mathrm{LT}=$ Annual lost tourism revenue in the absence of the dam

$\mathrm{OM}=$ Annual operation and maintenance cost

$\mathrm{RE}=$ Annual resettlement cost

$\mathrm{IF} \quad=$ Annual infrastructure relocation cost

$\mathrm{AC}=$ (Number of deaths/injuries during construction, operation and maintenance, and under special circumstances $) \times($ Economic valuation of death/injury $)+($ Annual economic damage cost of dam collapsing)

$\mathrm{NPV} t=(1+\text { Discount rate })^{-t} \times(\mathrm{EG} t+\mathrm{PG} t+\mathrm{CP} t-\mathrm{IN} t-\mathrm{AS} t-\mathrm{CC} t-\mathrm{FI} t-\mathrm{LT} t-\mathrm{OM} t-$ $\mathrm{RE} t-\mathrm{IF} t-\mathrm{AC} t)$

A.2 Data

Table A.1: Parameters and descriptions for Bakun (BHP) (US\$ $1=3.8$ Ringgits, Central Bank of Malaysia 2002).

(min, most likely, max) Description of each value

$\mathrm{GC}(0.5,0.7,2.4) \quad$ Original plan is $2.4 \mathrm{GW}$, but might be scaled down to $0.5-0.7 \mathrm{GW}$ (www.earthisland.org).

EO $(380,760,1500) \quad$ In China, each $\mathrm{kWh}$ of power shortage results in a loss of economic output of US\$ 0.38-1.5 [15].

TCC $(0.7,0.8,32) \quad$ The planned figure is US $\$ 4$ billion (www.idsnet.org). If we consider the possibility of GC being scaled down as above, the min and most likely should be reduced to US $\$ 0.083$ and 0.1 billion. Since the BHP is financially a highly uncertain project, set the worst 
Table A.1: Continued

(min, most likely, max) Description of each value

$\varphi(0.01,0.04,0.05)$

P0 $(0.33,0.5,0.66)$

FP $(0.005,0.3,0.6)$

$\operatorname{Tc}(12.5,13.5,17.5)$

PEo $(30,50,80)$

$\alpha(0.1,0.2,0.5)$

$\beta(0.6,0.8,0.9)$

$a(0.001,0.02,0.03)$

$\operatorname{EL}(0.6,0.7,0.9)$

case like India's Narmada Dam cost estimate being more than 8 times the original figure for all the min, most likely, and max [16]. The planned installed capacity in Malaysia will grow at $11 \%$ per annum on average up to 2007, while power demand is expected to grow by $8-10 \%$, or, in reality, the demand has registered an even slower growth of 6-7\% (Shabat Alam Malaysia Press Release; www.surforever.com/sam/pressrelease/lipis.htm).

Malaysia consumes one-third of the electricity consumption of Singapore (www.mint.gov.my/policy/nuc_energy/metp95_ asli.htm). Thus, Malaysia may need to increase its electricity supply by two-thirds to bring its economic development to the Singapore level. The min value is assumed to be half of this value, taking into account the possibility of electricity oversupply experienced before. The most likely is valued at $1 / 2$, assuming equal possibility of oversupply and demand growth.

US Fish and Wildlife Service studies show Savage Rapids Dam in Oregon has destroyed at least US\$ 5 million/year in fisheries benefits (The Pacific Coast Federation of Fisherman's Associations, Fisherman's News, May 1998). The National Marine Fisheries Service estimated the losses of Salmon fishery due to dams in the Colombia basin to be US $\$ 6.5$ billion in $1960-80$ alone [17]. The max value is assuming twice as much as the most likely value. These are also used for SBHP.

The min is the original plan (www.idsnet.org). According to the WCD Survey [1], $40 \%$ of the delayed projects show 1-year delay and $5 \%$ show a 5 -year delay.

These are min, average and max TNB tariff rates in 1999 (www.tnb.com.my/newtnb/custom/tr/et1.html).

Generally, the distribution of CC skewed to the left due to large costs at the initial stage. These are also used for IHP.

The distribution is likely to be skewed to the right, as the resettlement process is often slow. These are used for IHP.

The average annual loss rate of active storage due to sedimentation in the WCD Survey is $0.1 \%$ [1]. Some experts say the dam will not last for more than 50 years, i.e. $2 \%$ (www.earthisland.org). The max rate in the WCD Survey is 3\%. A relatively high rate is set in order to challenge project optimism.

70000 ha of affected rainforests including rich agricultural lands are valued based on the following studies. Projected economic value of the Peruvian Amazon if intact forest is sustainably harvested for fruits, latex, and timber is US\$ 6820/ha/year with the 5\% discount rate based on the annual yield in the region [18]. 
Table A.1: Continued

\begin{tabular}{|c|c|}
\hline (min, most likely, max) & Description of each value \\
\hline & $\begin{array}{l}\text { Constanza et al. }[19] \text { placed a value of US\$ } 1660 / \text { ha/year on the } \\
\text { 'ecological services' provided by rainforests excluding any } \\
\text { rewards from harvesting forests for food or raw materials. }{ }^{1} \\
\text { The most likely and max are } 20 \% \text { and } 50 \% \text { higher, as there should } \\
\text { be other benefits from the forest which are not valued. }\end{array}$ \\
\hline $\begin{array}{l}\mathrm{f} 20(-0.001,0.001 \\
\quad 0.02)\end{array}$ & $\begin{array}{l}\text { The attempt by TNB to raise the tariff in } 2001 \text { was not successful, so } \\
\text { assume very tiny deviations for the min and most likely. These are } \\
\text { also used for the following periods (max will be reduced by } 20 \% \\
\text { for every period). The tariff rate was increased by } 8 \% \text { in } 1997 \text {, i.e. } \\
8 \% / 4=2 \%[20] \text {. }\end{array}$ \\
\hline$\sigma(0.1,0.5,0.8)$ & $\begin{array}{l}\text { For the min, assuming the peak of the distribution is at the } \\
\text { beginning while completing fundamental work; for the most } \\
\text { likely, in the middle period during complicated and large-scale } \\
\text { work; for the max, at the end of the period. These are used for } \\
\text { SBHP and IHP. }\end{array}$ \\
\hline TRE $(0.08,0.16,0.32)$ & $\begin{array}{l}\text { The planned figure is } 0.08 \text { (www.earthisland.org). Assume the cost } \\
\text { overrun of } 2-4 \text { times [16]. }\end{array}$ \\
\hline C1 $(660,730,880)$ & $\begin{array}{l}\text { The most likely is calculated by the same procedure used by } \\
\text { Morimoto and Hope [3]. The min and max are } 10 \% \text { lower and } \\
20 \% \text { higher than the most likely. }\end{array}$ \\
\hline $\mathrm{C} 2(13,14,17)$ & Ibid. \\
\hline CM1 $(14.5,15.7,19.3)$ & The same values as in [3]. These are also used for IHP. \\
\hline CM2 $(414,60,552)$ & Ibid. \\
\hline OMC $(20,28,39)$ & $\begin{array}{l}\text { The min is the calculated value by Battelle ([21], Table 5.11). Cost } \\
\text { overrun of } 40 \% \text { is assumed [1]. }\end{array}$ \\
\hline $\mathrm{VD}(0.4,0.8,6.7)$ & The same values as in [3]. These are also used in SBHP and IHP. \\
\hline $\begin{array}{l}\text { VM }(0.0001,0.0004 \\
\quad 0.04)\end{array}$ & Ibid. \\
\hline $\operatorname{DCR}(0.3,0.8,1.9)$ & Ibid. \\
\hline $\operatorname{MCR}(170,310,340)$ & Ibid. \\
\hline $\mathrm{DCR}^{\prime}(0.32,0.57,0.63)$ & Ibid. \\
\hline $\operatorname{MCR}^{\prime}(7,12,13)$ & Ibid. \\
\hline $\begin{array}{l}\mathrm{DCR}^{\prime \prime}(6750,12150 \\
\quad 13500)\end{array}$ & $\begin{array}{l}\text { The same as in [3]. These are also used in IHP, but excluded for } \\
\text { SBHP, as the scale is small. }\end{array}$ \\
\hline $\begin{array}{l}\mathrm{MCR}^{\prime \prime}(34750,62550 \\
\quad 69500)\end{array}$ & Ibid. \\
\hline $\operatorname{ECL}(2,3.6,5.1)$ & $\begin{array}{l}\text { See Morimoto and Hope [2]. Cost overrun of } 40 \% \text { is assumed for } \\
\max [1] . \text { These are used also for IHP. }\end{array}$ \\
\hline$\pi(0.06,0.2,0.6)$ & $\begin{array}{l}\text { The min and the most likely are one-tenth and one-third of the max. } \\
\text { The removal of the Marmot and Little Sandy Dams which } \\
\text { generate } 22 \mathrm{MW} \text { is estimated to be US } \$ 22 \text { million. Based on this, } \\
\text { the Bakun needs } 2.4 \mathrm{GW} /(\text { mean TCC }=4)=0.6 \text {. }\end{array}$ \\
\hline
\end{tabular}


Table A.1: Continued

\begin{tabular}{|c|c|}
\hline (min, most likely, max) & Description of each value \\
\hline $\operatorname{TDC}(50,75,100)$ & $\begin{array}{l}\text { The expected life of a dam is } 50 \text { years. About } 5000 \text { large dams in the } \\
\text { world are now more than } 50 \text { years old [17, 22]. Assume } 50 \% \\
\text { more than the min for the most likely. The max is the final year of } \\
\text { the analysis. }\end{array}$ \\
\hline $\begin{array}{l}P=10^{-4} ; P^{\prime}=10^{-5} \\
\quad P^{\prime \prime}=10^{-5}\end{array}$ & The same values as in [3]. These are also used for IHP. \\
\hline
\end{tabular}

Note: PERT distribution (a special form of beta distribution) is used for all the parameters apart from $\mathrm{EO}, \mathrm{f} 20, \mathrm{DCR}, \mathrm{MCR}, \mathrm{DCR}^{\prime}, \mathrm{MCR}^{\prime}, \mathrm{DCR}^{\prime \prime}$, and $\mathrm{MCR}^{\prime \prime}$ for which a triangular distribution is used instead. The same distributions are used for SBHP and IHP.

1 'Ecological services' refer to climate/disturbance/water regulations, water supply, erosion control, soil formation, nutrient cycling, water treatment, genetic resources, recreation, and cultural services. Constanza's estimation is based on past studies and a few original calculations (mostly willingness of individuals to pay for ecosystem services).

Table A.2: Parameters and descriptions for Sharada-Babai (SBHP) (US\$ $1=76$ NRs, Central Bank of Nepal 2002).

\begin{tabular}{|c|c|}
\hline (min, most likely, max) & Description of each value \\
\hline EO $(110,280,1300)$ & $\begin{array}{l}\text { The min and the most likely are estimated losses to the Sri Lankan } \\
\text { economy for energy not generated in } 1990 \text { and } 1998 \text { prices, } \\
\text { respectively [23]. The max is a loss of economic output per kWh } \\
\text { of power shortages in China [16]. }\end{array}$ \\
\hline P0 $(0.1,0.75,0.9)$ & $\begin{array}{l}\text { The min and max are same as in [2]. About three-fourths of the } \\
\text { yearly precipitation in the subcontinent of South Asia falls within } \\
\text { just } 3 \text { months [24]. }\end{array}$ \\
\hline $\mathrm{GC}(0.06,0.08,0.093)$ & $\begin{array}{l}\text { The energy output of Victoria Dam in Sri Lanka is about } 31 \% \text { lower } \\
\text { than the planned figure [1]. The WCD Survey shows that the most } \\
\text { likely case is } 10 \% \text { below the target [1]. The max is the current } \\
\text { planned installed capacity [25]. }\end{array}$ \\
\hline $\operatorname{Tc}(5,6,10)$ & $\begin{array}{l}\text { The original plan is } 5 \text { years [26]. According to the WCD Survey, } \\
\text { about } 40 \% \text { of the delayed projects show a 1-year delay; } 5 \% \text { show } \\
\text { a 5-year delay [1]. }\end{array}$ \\
\hline $\begin{array}{l}\mathrm{f} 20(-0.013,0.01 \\
\quad 0.026)\end{array}$ & $\begin{array}{l}\text { The electricity price is increased by } 1 \% \text { in } 1999-2001 \text { [26]. }{ }^{1} \text { The } \\
\text { same values as in [2] for the min and max. }{ }^{2}\end{array}$ \\
\hline$\varphi(0.077,0.08,0.09)$ & $\begin{array}{l}\text { The number of electricity consumers increased by } 0.09 \% \text { (1998), } \\
0.08 \% \text { (1999), and } 0.077 \% \text { (2000) annually [25]. }\end{array}$ \\
\hline PEo $(69,77,92)$ & $\begin{array}{l}\text { Average electricity price in } 2000 \text { is US\$ } 77 \text { [26]. Assume } 10 \% \text { lower } \\
\text { than the most likely value for the min and } 20 \% \text { higher than the } \\
\text { most likely for the max. }\end{array}$ \\
\hline
\end{tabular}


Table A.2: Continued

\begin{tabular}{|c|c|}
\hline (min, most likely, max) & Description of each value \\
\hline TCC $(0.13,0.17,0.18)$ & $\begin{array}{l}\text { The min is the planned figure (WRS). About } 70 \text { hydropower projects } \\
\text { commissioned in the period 1915-86 financed by the World Bank } \\
\text { show average cost overruns of 30\% [27]. Average cost overruns } \\
\text { excluding extreme cases is } 40 \% \text { [1]. }\end{array}$ \\
\hline$\alpha(0.2,0.7,0.8)$ & The peak is likely to be at the end of the construction period [2]. \\
\hline$\beta(0.2,0.3,0$ & $\begin{array}{l}\text { The peak is more likely to occur near the beginning of the } \\
\text { construction period [2]. }\end{array}$ \\
\hline $\mathrm{BD}(0.01,0.018,0.019)$ & $\begin{array}{l}\text { The min is the damage caused by particulates and } \mathrm{CO}_{2}[23] \text {. The } \\
\text { most likely is the total damage caused by air pollution }\left(\mathrm{SO}_{2}, \mathrm{NO}_{x} \text {, }\right. \\
\left.\text { particulates, and } \mathrm{CO}_{2}\right) \text { emitted by diesel [23]. The max is } 10 \% \\
\text { higher than most likely. }\end{array}$ \\
\hline $\begin{array}{l}\text { IN }(0.004,0.005, \\
\quad 0.006)\end{array}$ & $\begin{array}{l}\text { The min is the estimated losses [25]. }{ }^{3} \text { The same cost overrun rates as } \\
\text { for TCC, } 30 \% \text { and } 40 \% \text {. }\end{array}$ \\
\hline $\begin{array}{l}\mathrm{IF}(0.0008,0.0011 \\
\quad 0.0012)\end{array}$ & $\begin{array}{l}\text { The min is the estimated cost }[25]{ }^{4} \text { The same cost overrun rates as } \\
\text { for TCC, } 30 \% \text { and } 40 \% \text {. }\end{array}$ \\
\hline $\begin{array}{l}\text { TRE }(0.0026,0.0036 \\
0.0039)\end{array}$ & $\begin{array}{l}\text { The min is the planned figure [25]. The actual number of resettled } \\
\text { people is } 35 \% \text { higher than the estimated figure according to the } \\
\text { WCD Survey [1]. The actual number is } 47 \% \text { higher than the } \\
\text { estimated figure among the projects financed by the World Bank } \\
\text { [28]. }\end{array}$ \\
\hline $\begin{array}{l}\mathrm{OMC}(0.0018,0.0023 \\
0.0026)\end{array}$ & $\begin{array}{l}\text { The min is the planned figure (WRC). The same cost overrun rate as } \\
\text { for TCC are used, } 30 \% \text { and } 40 \% \text {. }\end{array}$ \\
\hline$a(0.0005,0.001,0.002)$ & $\begin{array}{l}\text { The most likely is same as the min for BHP. This issue involves huge } \\
\text { uncertainty. Assume the min and max are half and twice the most } \\
\text { likely. }\end{array}$ \\
\hline$\pi(0.07,0.23,0.7)$ & $\begin{array}{l}\text { The max is calculated in the same manner as in [2]. The min and the } \\
\text { most likely are one-tenth and one-third of the max, respectively. } \\
\text { The removal of the Marmot and Little Sandy Dams which } \\
\text { generate } 22 \mathrm{MW} \text { is estimated to be US } \$ 22 \text { million. Based on this } \\
\text { figure, the SBHP needs } 0.093 \mathrm{GW} /(\mathrm{TCC}=0.13 \text { ) }\end{array}$ \\
\hline $\operatorname{TDC}(50,75,100)$ & Same as in $[2]$ \\
\hline
\end{tabular}

\footnotetext{
${ }^{1}$ See also www.nea.org.np/tariffrate.htm.

${ }^{2}$ The same minimum and maximum values are used for every period. The most likely value is assumed to decrease by $20 \%$ for every period.

${ }^{3}$ Land acquisition [agricultural land (268 ha) and forest land (33 ha) $=0.311$ GNRs.

${ }^{4} 2$ suspension bridges $=5,000,000$ Rs; 2 temples $=40,000 \mathrm{Rs} ; 1$ school $=1,400,000 \mathrm{Rs} ; 5$ roads $=50,000,000 \mathrm{Rs} ; 5$ foot trails $=500,000 \mathrm{Rs} ; 6$ irrigation schemes $=6,000,000 \mathrm{Rs} ; 1$ health post $=100,000 \mathrm{Rs} ; 1$ post office $=80,000 \mathrm{Rs} ; 1$ police office $=1,300,000 \mathrm{Rs} ; 3$ water mills $=150,000 \mathrm{Rs} ; 1$ telephone office $=50,000$ Rs.
} 
Table A.3: Parameters in the CBA model and descriptions for Ilisu (IHP) (US\$ $1=1360000 \mathrm{TL}$, Central Bank of Turkey 2002).

(min, most likely, max) Description of each value

\begin{tabular}{ll}
\hline EO $(380,760,1500)$ & Same as BHP above. \\
NT '0000 $(13,28,103)$ & About 30,000 pilgrims visit Hasankeyf annually
\end{tabular}

NT '0000 $(13,28,103) \quad$ About 30,000 pilgrims visit Hasankeyf annually

(www.khrp.org/publish/p1999/ilisuReport.htm). About 1 million tourists are predicted to visit the GAP region in 2005 (www.international.icomos.org/risk/turkey_2000.htm), of which assume $10 \%$ and $25 \%$ for min and max.

TCC $(1.52,6.08,9.12) \quad$ The original plan (http://www.rivernet.org/turquie/ilisu.htm); assumption of cost overruns of 4 and 6 times (2-4 times China TGP; 6 times Brazil Itaipu; [16]).

$\mathrm{GC}(0.8,1.1,1.2)$

$\varphi(0.012,0.026,0.029)$

The energy output of Victoria Dam in Sri Lanka is about $31 \%$ lower than the planned figure [1]. The WCD Survey shows that the most likely case is $10 \%$ below the target. The max is the current planned installed capacity.

The annual rates of decrease in the proportion of hydro and renewable planned installed capacity out of the total capacity in Turkey are 0.012 (1997-2010), 0.026 (2010-20), and 0.029 (2010-20) (http://www.dolph.com.tr/energy.htm). The max is triple of the min.

P0 $(0.52,0.7,0.75)$

FP $(0.0025,0.005,0.3)$

$a(0.001,0.02,0.033)$

The domestic energy production can only meet $48 \%$ of the requirements (www.parliament.the-stationeryoffice.co.uk/pa/cm200001/cmselect/cmtrdind/360/36008.htm). The potential of hydropower in Turkey is presently $<30 \%$ developed [7]. The IHP is a peak power plant, so assume $75 \%$.

The most likely is same as the min for BHP above. The min is half of the most likely as fishery in this area is mainly for locals. The National Marine Fisheries Service estimated the losses of Salmon fishery due to dams in the Colombia basin to be US\$ 6.5 billion during 1960-80 alone [17].

The min is same as the min for IHP above. Experts foresee 30-50 years of functional life for the dam due to the high possibility of the dam being filled with rubble.

$\operatorname{AL}(0.5,0.55,0.75)$

A 4-foot bronze candelabrum dating to the Han Dynasty was sold for US\$ 2.5 million at the International Asian Art Fair in New York (www.archaeology.org/online/news/china.html). At least 200 or even some hundred more sites would be inundated by Ilisu Dam [29]. The exact number of antiquities in the sites is unknown. Assume $10 \%$ (most likely) and 50\% (max) as many antiquities exist in the area.

EL $(0.008,0.013,0.016) \quad$ CEB [23] estimated the value of land at 26-764 US\$/ha/year. Thus, assume the following. The dam will submerge 7353 ha of good agricultural land (US\$ 764/ha/year), 4820 ha of medium-low quality land (US\$ 500/ha/year), 15,675 ha of land not suitable for 
Table A.3: Continued

\begin{tabular}{|c|c|}
\hline (min, most likely, max) & Description of each value \\
\hline & $\begin{array}{l}\text { growing crops (US\$ } 26 / \text { ha/year). The most likely and max are } \\
\text { assumed to be } 50 \% \text { and } 100 \% \text { higher than the min. }\end{array}$ \\
\hline$\varepsilon(0.8,0.9,1)$ & $\begin{array}{l}\text { Since Hasankeyf is the main attraction for both tourists and pilgrims, } \\
\text { assume very high reduction in rate of visitors. }\end{array}$ \\
\hline $\mathrm{RS}(560,620,680)$ & $\begin{array}{l}\text { The } 1999 \text { tourism recipient in Turkey is } 620 \\
\text { (http://www.gso.org.tr/turkey.htm); } 10 \% \text { lower and higher for min } \\
\text { and max. }\end{array}$ \\
\hline Tc $(7.5,8.5,12.5)$ & $\begin{array}{l}\text { The min is the original plan [7]. According to the WCD Survey [1], } \\
\text { about } 40 \% \text { of the delayed projects show a 1-year delay; } 5 \% \text { show } \\
\text { a 5-year delay. }\end{array}$ \\
\hline PEo $(72,80,88)$ & $\begin{array}{l}\text { The most likely figure is the tariff rate effective from March } 2002 \\
\text { (www.tedas.gov.tr). The min and max are 10\% higher and lower } \\
\text { than the tariff. }\end{array}$ \\
\hline $\mathrm{f} 20(0,0.001,0.02)$ & $\begin{array}{l}\text { The average rate of change in the electricity tariff in Turkey is } 0.02 \\
\text { from October to November 2001(Turkish Electricity Distribution } \\
\text { Corporation). The min and most likely assume small negative and } \\
\text { no deviations in tariff rates. }\end{array}$ \\
\hline TRE $(0.57,1.14,2.28)$ & $\begin{array}{l}\text { The planned figure is } 0.57 \text { (http://www.dsi.gov.tr/ilisu1.htm). } \\
\text { Assume } 2 \text { and } 4 \text { times cost overruns [16]. }\end{array}$ \\
\hline $\mathrm{C} 1(700,780,940)$ & $\begin{array}{l}\text { The most likely is calculated in the same manner as in [3]. The min } \\
\text { and max are } 10 \% \text { lower and } 20 \% \text { higher than the most likely. }\end{array}$ \\
\hline $\mathrm{C} 2(18,20,24)$ & Ibid. \\
\hline OMC $(20,28,39)$ & $\begin{array}{l}\text { The min is the calculated value by Battelle ([21], Table 5.11). Cost } \\
\text { overrun of } 40 \% \text { is assumed [1]. }\end{array}$ \\
\hline$\pi(0.079,0.26,0.79)$ & $\begin{array}{l}\text { The removal of the Marmot and Little Sandy Dams which generate } \\
22 \mathrm{MW} \text { is estimated to be US\$ } 22 \text { million. Based on this figure, } \\
\text { the IHP needs } 1.2 \mathrm{GW} /(\mathrm{TCC}=1.52) \text {. The min and the most } \\
\text { likely are one-tenth and one-third of the max, respectively. }\end{array}$ \\
\hline $\operatorname{TDC}(30,50,100)$ & $\begin{array}{l}\text { The expected life of a dam is } 30-50 \text { years. The max value is the final } \\
\text { year of the analysis. }\end{array}$ \\
\hline
\end{tabular}

\section{REFERENCES}

[1] WCD, Dams and Development: A New Framework for Decision-Making, Earthscan: London, 2000.

[2] Morimoto, R. \& Hope, C., The CBA model for the Three Gorges Project in China. Impact Assessment and Project Appraisal Journal, 22(3), pp. 205-220, 2004.

[3] Morimoto, R. \& Hope, C., An extended CBA model of hydro projects in Sri Lanka. International Journal of Global Energy Issues, Special issue on energy and renewable energy with economic development in developing countries, 21(1/2), pp. 47-64, 2004.

[4] Asian Development Bank (ADB), Technical Assistance Report for Nepal, Manila, 2004.

[5] Pokharel, S., Hydropower for energy in Nepal. Mountain Research and Development, 12(1), pp. 4-9, 2001.

[6] Mahapatra, R., Power the people. Appropriate Technology, January-March 2001. 
[7] Ilisu Engineering Group (IEG), Ilisu Dam and HEPP Environmental Impact Assessment Report, April 2001.

[8] Dixon, J.A., Scura, L.F., Carpenter, R.A. \& Sherman, P.B., Economic Analysis of Environmental Impacts, 2nd edn, The Asian Development Bank and the World Bank; London, 1994.

[9] Carver, M., On archaeological value. Antiquity, 70, pp. 45-56, 1996.

[10] Carman, J., Garnegie, G.D., \& Wolnizer, P.W., Is archeological valuation an accounting matter? Antiquity, 73, pp. 143-148, 1999.

[11] Darvill, T., Saunders, A. \& Startin, B., A question of national importance: approaches to the evaluation of ancient monuments for the monuments protection programme in England Antiquity, 61, pp. 393-408, 1987.

[12] Lipe, W.D., Value and meaning in cultural resources. Approaches to the Archaeological Heritages, ed. H.F. Cleere, Cambridge University Press, pp. 1-11, 1984.

[13] Schaafsma, C.F., Significant until proven otherwise: problems versus representative samples. Archaeological Heritage Management in the Modern World, ed. H. Cleere, Unwin Hyman: London, pp. 38-51, 1989.

[14] Morimoto, R. \& Hope, C., Making the case for developing a silent aircraft. Transport Policy, 12(2), pp. 165-174, 2005.

[15] MOF, Energy in China, The Ministry of Energy Press: Beijing, 1990.

[16] McCully, P., Silenced Rivers: The Ecology and Politics of Large Dams, Zed Books: London \& New Jersey, 1996.

[17] McCully, P., Taking down bad dams. World Rivers Review, 12(4), August 1997.

[18] Peters, C.M., Gentry, A.H. \& Mendelsohn, R.O., Valuation of an Amazonian rainforest. Nature, 339, pp. 655-656, 1989.

[19] Constanza, R., et al., The value of the world's ecosystem services and natural capital. Nature, 387, pp. 253-260, 1997.

[20] TNB, Kenyir Hydroelectric Power Plant Project II - Preliminary Works, Progress Report 10, February, 2001.

[21] Battelle, China's Electric Power Options: An Analysis of Economic and Environmental Costs, Battelle Memorial Institute: Washington, DC, 1998.

[22] Wade, B., Bringing down the dams. The American City \& County, Pittsfield, June 1999.

[23] CEB, Environmental impact assessment for the Upper Kotmale Hydro Project, 1994.

[24] Lincoln, K., Subcontinent: the wasted waters; Himalayan plunder; resources and rights; buyer's market. Far Eastern Economic Review, 2 February 1989.

[25] WRC and SILT, Environmental Impact Assessment Study, Final report, 2001.

[26] NEA, NEA Financial Year 1999/2000: A Year in Review, August 2000.

[27] Bacon, R.W. \& Besant-Jones, J.E., Estimating construction costs and schedules: experience with power generation projects in developing countries. Energy Policy, 26(4), pp. 317-333, 1998.

[28] World Bank, Resettlement and development: the bankwide review of projects involving involuntary resettlement 1986-1993, Environment Department Paper 32, The World Bank: Washington, DC, 1996.

[29] Corner House Research (CHR), et al., Cultural Heritage: Review of the EIA Report for the Ilisu Dam and HEPP, September 2001. 